\title{
The Interplay between Gender, Learning Approaches and Academic Performance in Chinese Sub-Degree and Degree Students
}

\author{
Yiu-Kong Chan (Corresponding author) \\ School of Professional and Continuing Education, The University of Hong Kong \\ Hong Kong SAR, China \\ E-mail: ringo.chan@hkuspace.hku.hk \\ Andy C N Kan \\ Lee Shau Kee School of Business and Administration \\ The Open University of Hong Kong \\ Hong Kong SAR, China \\ E-mail: akan@ouhk.edu.hk
}

Received: December 6, 2016 Accepted: February 6, 2017 Published: February 25, 2017

doi:10.5296/gjes.v3i1.10781 URL: http://dx.doi.org/10.5296/gjes.v3i1.10781

\begin{abstract}
The community college has been the alternative choice for secondary school graduates on the verge of enrolling in government-funded universities in the Hong Kong higher education system over the past decade. Open University of Hong Kong provides its business degree distance learning programme through face-to-face teaching mode for full-time students. This study examines the relationship of gender, learning approaches and academic performance among 250 Hong Kong Chinese sub-degree and degree students. Students participated in the study responded to the Biggs's Revised Two-Factor Study Processes Questionnaire (R-SPQ-2F) and McAuley's Revised Causal Dimension Scale (CDSII). The results indicate that the deep approach and academic performance is positively related. Implications of the findings are discussed for tertiary teachers and counselors.
\end{abstract}

Keywords: Learning approach, Distance learning, Academic performance, Sub-degree and degree students 


\section{Introduction}

Many educators have believed that academic performance is largely due to individual differences in ability. Many studies over the past decades tried to examine key determinants of academic performance in an attempt to develop adequate interventions to enhance teaching and learning in different school settings. Studies have focused on the investigation of individual variables other than ability such as gender, locus control, or self-concept. Among other factors, learning approaches appear to be major predictors of scholastic performance. It is important to identify student characteristics that can be enhanced in school setting to promote better academic performance.

While little research has been conducted on full-time Chinese sub-degree and degree students in different higher education institutions in Hong Kong, this study examines relationships of gender, learning approaches, locus of control and academic performance of these students. The trajectory for success may differ for two different higher education institutions.

\section{Review of Literature}

The Hong Kong educational system is regarded as competitive and examination-oriented (Hau, 1992). Entry to government-funded universities is very selective and assessed by a series of public examinations in Hong Kong. Education is considered as a means of obtaining upward mobility and economic enhancement. Only $2 \%$ of the 17-to-20-year-old age group could access higher education in the 1970s in Hong Kong. The government altered its policy in 1989 to expand the tertiary education sector from $6 \%$ in the 1980 s to $18 \%$ in the 1990 s. This policy shift is partly due to a large demand for a well-educated workforce and the partial removal of highly qualified workforce through emigration during the pre-1997 period. About $18 \%$ of the relevant age group was able to receive government-funded university education in 2013. The Hong Kong Education Commission document "Learning for Life: Framework of Education Reform" (EC HKSAR, 2000) emphasized the need to provide a diversified, multi-channel and multi-layer higher education system in Hong Kong. A target of increasing the percentage of senior secondary school graduates to receive higher and further education was set by the government from $30 \%$ to $60 \%$ over the next decade in 2000 . The target had already been met by 2005 because the number of self-financed sub-degree students such as higher diploma and associate degrees offered by tertiary institutions had increased more than 550 percent from 2621 to 17,077 from 2000 to 2005 . Other developed nations such as South Korea and the US had reached the 80 percent target for participation of high school-leavers in higher and further education and Australia reached 70 percent (Chiu, 2008).

Community college education has been offered in Hong Kong for 14 years. In response to the Government's Education Commission Report in 1999, the first Community College was established in Hong Kong since 2000 in order to provide a multi-layer higher education system for secondary school graduates who were aged between 17 and 21 years. Both associate degrees and higher diplomas programmes are provided with a two-year curriculum of 450 teaching hours per year on a full-time basis. Following American community college education, about $50 \%$ of generic courses, namely Chinese, English, arts and humanities, science and technology and ways of knowing are covered in the associate degree curriculum. 
Higher diploma curriculum aims to provide a solid foundation in a specialized area which constitutes about $60 \%$ of specialized courses. It is expected that associate degrees are more academically oriented and higher diplomas are more vocational focus. Both programmes are equivalent to $50 \%$ of a four-year university degree of the North American education system or one-third of a three-year university degree of the British system. Both programmes provide a wide range of courses from arts, business to Chinese medicine in an attempt to address students' interests. Community colleges are one of key points of access to Hong Kong government-funded universities and play a crucial role in offering further educational opportunities to secondary school graduates.

Sub-degree programmes are often taken by students from less advantaged academic background who were not able to achieve sufficiently high grades in public examinations to obtain an offer on a full-time undergraduate programme at the university due to a limited number of government-funded places in Hong Kong. Using the sub-degree programme as a stepping-stone into university, therefore, is a major objective for students who did not achieve the grades in advanced level examinations to gain admittance to the government-funded universities in Hong Kong. Some students have been prevented from completing schooling because of economic factors. The Hong Kong community college system is modeled after both the American and British higher education system. The development of the associate degree was influenced by American model. The higher diploma was modelled after the British system. The government only offers partial financial assistance to those sub-degree students including means-tested grants, non-means-tested loans and travel subsidies. The HK $\$ 5$ billion Continuing Education Fund sponsors students to pursue continuing education, training courses and sub-degree programmes to facilitate the expansion of higher education sector. The government has used a 'public-aided approach' to expand the higher education sector from public dominance to a public-private combination.

More of the "average" students are able to receive higher education. The government educational policy of expansion of higher education and the sub-degree programmes are major developments in post-secondary education in Hong Kong over the past seven years. Mindful of budgetary constraints, the Hong Kong government intended that the expansion of higher education would be driven by self-financing education institutions. The self-financing associate degree or higher diploma programmes are seen as bridging programmes to the degree programme in Hong Kong. Under this new articulated system of post-secondary education, more students from less advantaged academic backgrounds are able to access higher education. More students from less advantaged academic background are able to pursue higher education. Given the specific nature and academic background of these students, there is a need to develop a greater understanding of major factors to shape their educational success.

With a portray of examination-oriented and utilitarian type of education, there have been anecdotal descriptions about Hong Kong Chinese students as rote-learners. It is argued that the examination-oriented entry selection results in a didactic teaching and rote-learning approach for most secondary school students in Hong Kong (Watkins \& Biggs, 2001). For most of the sub-degree students, their previous educational experiences can be summarized as 
didactic teaching and passive learning in response to tightly structure examination-oriented courses. Research studies in various countries (Entwistle, 2009; Kember et al., 2011) show that students are likely to adopt a surface approach rather than a deep approach to learning if the learning environment is unfavourable such as didactic teaching approach, heavy workloads and lack of intrinsic motivation.

Research by Kember et al. (2011) argue that the perception of Hong Kong students being prone to rote-learning is partly due to the nature of the curriculum and the teaching environment such as a heavy workload, surface assessment demand, lack of intrinsic motivation or didactic teaching style rather than as an inherent characteristic of Hong Kong students. Several research findings have reported that Hong Kong Chinese students tend to link the process of memorization and understanding to enhance learning (Biggs, 1993; Watkins \& Biggs, 2001). Students adopt a 'narrow orientation' by systematically working through material section by section, tending to first understand and then to memorize what they had learnt. Hong Kong tertiary students appear to be good at rote-learning and memorization and they are unwilling to think more deeply about their subject. Students were perceived as having a non-critical and non-analytical approach of learning. The empirical results of learning characteristics of Hong Kong Chinese students are mixed. Biggs (1993) reported that Hong Kong Chinese students achieved higher scores on the deep approach than their English speaking students at Hong Kong international schools.

\section{Gender, Locus of Control, Learning Approach and Academic Performance}

There are a large number of studies to examine learning approaches and academic performance (Biggs, 1993; Cano, 2005; Hay, 2007; Sternberg, 1997). Biggs's model of students' learning approaches suggests three components - presage-process-product (3P) mode in the classroom. Presage addresses experiences before learning takes place. Process concerns learning strategies. Product focuses on learning outcomes after learning has taken place. Biggs's 3P model addresses three components in the classroom which propose that personal and situational factors influence a student to adopt a specific approach to learning that influences the learning outcomes achieved.

According to 3P model, two major learning approach take place. A deep approach involves searching meaning and relating information to knowledge already acquired. A surface approach acquires rote learning and places emphasis on detail rather than relating links between concepts. The deep approach is expected to be conductive for learning in higher education. Learning approaches can be affected by variables such as heavy course work, didactic teaching method, or over-lecturing in Hong Kong (Diseth, 2011). It has been argued that students using the deep approach are often academically high achievers (Fenollar, Roman, \& Cuestas, 2007; Ho \& Hau, 2008; Sins et al., 2008). Empirical studies are mixed regarding the relationship between deep approach and academic achievement. Studies by Trigwell, Ashwin, and Millan (2013) and Diseth et al. (2006) found that no direct relationship between deep approach and academic performance was observed. Lizzio, Wilson, and Simons (2002) found a positive relationship between surface approach and academic performance among commerce students. 
Locus of control is one of the most researched constructs in the area of personality. The locus of control refers a person belief in relation to the placement of control over his or her life events (Jonassen \& Grabowski, 1993). It is believed that an individual student's locus of control shows his or her attitude and motivation for learning. An internal locus of control indicates that the student takes personal responsibility for his academic performance. An external locus of control refers his belief of little personal control over his learning (Sinclaire, 1991). Appreciation of responsibility is associated with better achievement outcomes. Findley and Cooper (1983) reported that low perceived control is associated with poor academic performance. Watkins (1984) argued that if students believe that they have control over their own learning, they are more like to use the deep approach. Perceived lack of control is likely to lead to the belief of learning as a memory task. It is hypothesized that for students to want to adopt deep learning needs confidence in their own academic ability and a conviction that they should not reply too much on the teacher but take responsibility for their own learning. It is predicted that an external locus of control should be correlated with surface learning.

Gender differences in learning approaches might emerge in particular academic or cultural contexts, with particular disciplines, curricula or programme structure, or on different academic assessment methods. In general, female students work harder, are better organized, spend more time on course work and less distracted in the classroom than do male students (Davies \& Brember, 2001). The studies concerning gender differences in learning approaches are far from conclusive. Meinz and Salthouse (1998) found that men and women appear to perform at similar levels in learning contexts which require the retrieval of memory, but women seem to out-perform men in learning contexts requiring the acquisition of new information. Smith and Naylor (2001) found that women were more likely than men to be awarded good degrees in the UK. Richardson and King (1991) found that there is no gender difference in learning approaches by using the Study Process Questionnaire (SPQ) and the Approaches to Study Inventory (ASI). Richardson (2006), however, found that gender had no effect on the students' academic performance in distance education. Few studies have explored the gender difference in Hong Kong full-time sub-degree and degree students. The objective of this study was to examine the interplay between gender, learning approach, locus of control and academic performance among Hong Kong Chinese sub-degree and degree students.

\section{Participants}

Research participants for this study were 128 students from Higher Diploma in Business of HKU SPACE and 122 students from full-time face-to-face Bachelor of Business Administration programmes of the Open University of Hong Kong (OUHK). The students' age ranged from 18 to 26 years with an average of 21 years old. All participants were studying not only in business major but also in face-to-face programmes. The number of face-to-face teaching hours, including lectures and tutorials, for all participants is similar. OUHK full-time students have more academic support such as study guide for each course which normally would not be provided by traditional face-to-face universities or colleges.

The content of full-time face-to-face courses in the OUHK is basically the same as the 
courses offered through the distance-learning mode in the OUHK, except the face-to-face teaching session component. In other words, the OUHK full-time face-to-face students, in additional to face-to-face teaching sessions, also have full distance-learning support from OUHK, including accessing the softcopy of the written distance-learning course materials and the OUHK's Online Learning Environment (OLE). OUHK's distance-learning course materials are developed by subject experts and tailored specifically for Hong Kong students. The OLE is the OUHK's online platform through which lecturers, tutors and students can easily communicate with each other. Volunteer students were surveyed in class using a non-probabilistic sampling procedure. All measures were gathered in the classroom by researchers who clearly articulated the purpose and response choices of the measures to students.

\section{Research Methodology}

This study employed Biggs's Revised Two-Factor Study Process Questionnaire (R-SPQ-2F) to measure learning approach. The R-SPQ-2F is a self-report instrument composed of 20 items falling into four subscales. Participants rated themselves on a 5-point Likert scale ranging from 1 (low) to 5 (high). The four subscales are surface-motive, surface-strategy, deep-motive and deep-strategy. Examples of items from the R-SPQ-2F are (1) "My aim is to pass the course while doing as little work as possible." (surface motive) and (2) "I test myself on important topics until I understand them completely." (deep strategy). The two overall scales are surface and deep, with each scale being consisted of the motive and strategy subscales. Confirmatory factor analysis showed a good fit with the R-SPQ-2F by using Hong Kong tertiary students (Biggs, Kember, \& Leung, 2001). It found that tertiary students' learning approaches could be interpreted in a hierarchical structure that has two second-order factors including deep and surface learning. The R-SPQ-2F score was used to identify deep learning approach and surface learning approach and GPA score was used as an index of academic performance.

The Revised Causal Dimension Scale (CDSII) was used to measure the locus of control. The participants decided on their perceived reasons for their academic success and failure in response to four various dimensions of causality which included locus of control, stability, personal control and external control using nine-point rating scales. The Revised CDSII was developed by McAuley, Duncan and Russell (1992) so that the participant could directly indicate how he or she views underlying dimensions of their causes. Confirmatory factor analyses were conducted to test the hypothesized factor structure and the results reported that the model fitted the data.

Grade Point Average (GPA) was utilized to examine academic performance. The course GPA is a weighted average of the GPAs for all compulsory subjects, which is measured on a scale from A (excellent) to $\mathrm{F}$ (fail), from the commencement of their study to the point at which the survey was conducted. These grades were converted to numbers for data analysis with higher numbers pointing to better grades $(\mathrm{A}=5, \mathrm{~B}=4, \mathrm{C}=3, \mathrm{D}=2, \mathrm{~F}=1)$. The grade was calculated by averaging the percentages achieved in semester assessments. Students were assessed using a variety of methods such as examinations, continuous assessment, projects, 
presentations, essays. GPA was obtained by formulate approximately assigning an ' $A$ ' to students achieving final assessment percentages of $85 \%$ or above, a ' $\mathrm{B}$ ' to students achieving final assessment percentage between $60 \%$ and $85 \%$, a ' $C$ ' to students with final assessment percentage between $50 \%$ to $60 \%$, a ' $\mathrm{D}$ ' to students with final assessment percentage between $40 \%$ and $50 \%$ and ' $\mathrm{F}$ ' to students with final percentage below $40 \%$.

\section{Data Analysis}

Hierarchical regression analysis was conducted on the data of the whole sample in order to test the predictability of academic performance. Table 1 outlines the results of the hierarchical regression analysis of community college students and Open University degree students. Results showed that GPA was significantly related with learning approach and gender for community college students. Locus of control did not demonstrated significant regression coefficient.

The dummy variable to identify degree and community college students was significantly different. The results suggest that the deep approach is one of key variables affecting academic performance for both sub-degree and degree students. Detailed statistics indicating these relationships are presented in Table 1.

Table 1. Regression model summary (Dependent Variable: Grade Point Average)

\begin{tabular}{|l|c|c|c|}
\hline Variables & Beta & SE & $\mathrm{t}$ \\
\hline Gender & $.335^{* *}$ & .137 & 2.445 \\
\hline Locus of control & .071 & .150 & .473 \\
\hline Learning approach & $.409^{* *}$ & .166 & 2.464 \\
\hline Dummy & $0.916^{* * *}$ & .137 & 6.686 \\
\hline $\mathrm{F}(4,245)=15.524 * * *$ \\
\hline$R^{2}=.202 \quad$ Adjusted $R^{2}=.189$ \\
\hline
\end{tabular}

Note. $* * \mathrm{p}<0.05 ; * * * \mathrm{p}<0.01$.

Use of multiple regression, with GPA as the dependent variable, showed that both learning approach and gender emerged as variables explain about $19 \%$ of the variance (adjusted $R^{2}$ $=.189, \mathrm{p}<0.01)$.

Table 2. Summary of hierarchical regression analysis for variables relating with academic performance as dependent variable of community college students

\begin{tabular}{|l|c|c|c|}
\hline Variables & Beta & $\mathrm{t}$ & $\mathrm{p}$ \\
\hline Gender & 239 & 1.432 & .155 \\
\hline Locus of control & .116 & .635 & .527 \\
\hline Learning approach & .962 & 4.722 & .000 \\
\hline $\mathrm{F}(3,124)=8.258^{* *}, \mathrm{p}<0.001$ & & \\
\hline$R^{2}=.163 \quad$ Adjusted $R^{2}=.144$ &
\end{tabular}

Note. $* * \mathrm{p}<0.05$. 
Table 3. Summary of hierarchical regression analysis for variables relating with academic performance as dependent variable of Open University sub-degree students

\begin{tabular}{|l|l|l|l|}
\hline Variables & Beta & $\mathrm{t}$ & $\mathrm{p}$ \\
\hline Gender & .568 & 2.637 & .00953 \\
\hline Locus of control & -.297 & -1.27 & .207 \\
\hline Learning approach & .254 & 9.765 & .331 \\
\hline $\mathrm{F}(3,118)=2.881, \mathrm{p}=0.0389$ & \\
\hline$R^{2}=.0699 \quad$ Adjusted $R^{2}=.0456$ & \\
\hline
\end{tabular}

Table $2 \& 3$ outline the results of the hierarchical regression analysis of community college students and Open University students respectively. Results showed that GPA was significantly related with learning approach for community college students. Gender and locus of control did not demonstrated significant regression coefficients. Both gender and learning approach were weakly related with GPA for Open University students. It is found that both academic performance of both community college students and Open University students are positively associated with the learning approach. The result found that locus of control did not link with the academic performance for both groups of students.

\section{Discussion and Conclusion}

The purpose of this exploratory study was to examine the relationship between gender, learning approaches, locus of control and academic performance. Results from a multiple regression analysis indicated that learning approach and gender significantly correlated with the GPA. This study's findings confirmed the predicted relationship and provide support for the idea that the importance of using deep approach in tertiary education. Locus of control did not explain academic performance in our analysis, contrary to the hypotheses. It appears that both community college and university students are encouraged to use the deep approach with an aid of interactive teaching and learning environment in both institutions.

Although two groups of students come from different academic background, the link between learning approach and GPA is consistent in this case. Learning environment and course assessment are similar for two groups of students. A number of variables, however, may affect the link between learning approaches and academic performance. First, a difference between assessment systems of two institutions is needed to be taken into account. Sternberg (1997) argued that the assessment format has a strong impact on how students approach their study. Second, learning approaches and academic performance may form a complex non-linear relationship rather than a direct correlation in different disciplines. The same student may adopt different learning approaches in response to different academic context. Previous studies (Lizzio, Wilson, \& Simons, 2002; Trigwell, Ashwin, \& Millan, 2013) argued that students were likely to adopt the surface approach rather than the deep approach due to a variety of factors such as didactic teaching, heavy workloads and learning environment. For example, in some circumstances, surface approach may be appropriate in response to assessment format by the educational institutions. 
Ho and Hau (2008) suggested that GPA might not have adequately reflected the learning outcomes that students had achieved through the use of learning approach. Considering other variables known to explain academic performance such as self-efficacy (McKenzie \& Schweitzer, 2001), learning environment (Entwistle \& Peterson, 2004), and emotional intelligence (Austin, Evans, Goldwater \& Potter, 2005) is required. Recent studies showed that other variables such as self-efficacy (Diseth, 2011; McKenzie \& Schweitzer, 2001; Prat-Sala \& Redford, 2010), personality (Furnham, Chamorro-Premuzic, \& McDougall, 2003; Trigwell, Ashwin \& Millan, 2013), learning context and culture environment (Kember et al, 2011) partly affected academic performance. For example, the level of cognitive ability appears to be more homogeneous and restricted in range in higher education. Asian students believe in a direct relationship between good higher education, better job prospect, and social advancement.

Hypotheses has been put forward concerning gender differences in academic performance in Britain and North America higher education institutions over the past two decades. Men and women appear to perform at similar levels in learning tasks requiring the retrieval of information. It is argued that women seem to outperform men in situations requiring the acquisition of new information (Meinz \& Salthouse, 1998 and there was gender difference in academic performance with advancing age. The results revealed that women aged 21 or over were more likely to obtain an honours degree than men in the UK. Qualitative studies by Thomas (1988) revealed significant differences in the learning experiences of men and women between arts programmes where men often comprise the minority of students and science programmes where men often comprise the majority of students. While the present study only focuses on business students, learning experiences of men and women in different discipline context need to be explored in the case of Hong Kong sub-degree and degree students. Although this finding does not warrant causal relationship between the two variables examined, the result has practical implications for lecturers to aware a possibility of gender difference in academic performance.

Offering high quality support services in higher education institutions is important in order to enhance students' chances of scholastic success. This study suggests that lecturers might help their students to enhance learning by cultivating the use of deep approach. Teachers and counsellors can help students develop more diligent study habits. There are three limitations of this research. First, it conflates academic performance with learning outcome. Scouller and Prosser (1994) argued that high-quality learning outcome is not often the same as high academic performance. The quality of learning outcome can be low if the course assessment rewards high academic achievement by using surface approach. It, however, may not be true in the context of this study, where the course assessment encourages the deep approach in community colleges. Second, no other measures are used to examine that the way students replied to the questionnaires is reflective of how they actually behave. Qualitative methods may reveal insights into the relationship between learning approach and academic performance in this context. Third, the study is limited by the sample size. Larger samples of students are drawn from a wider range of disciplines in different community colleges may shed further light on the relationship between locus of control, learning approaches and 
academic performance.

\section{References}

Austin, E. J., Evans, P., Goldwater, R., \& Potter, V. (2005). A preliminary study of emotional intelligence, empathy and exam performance in first year medical students. Personality and Individual Differences, 39(8), 1395-1405. https://doi.org/10.1016/j.paid.2005.04.014

Biggs, J. B. (1993). What do inventories of students' learning processes really measure? A theoretical review and clarification. British Journal of Educational Psychology, 63(1), 1-17. https://doi.org/10.1111/j.2044-8279.1993.tb01038.x

Biggs, J. B., Kember, D., \& Leung, D. Y. P. (2001). The revised two-factor Study Process Questionnaire: R-SPQ-2F. British Journal of Educational Psychology, 71(1), 133-149. https://doi.org/10.1348/000709901158433

Chiu, L. M. W., \& Cunich, P. (2008). HKU SPACE and its Alumni: The First Fifty Years. Hong Kong University Press.

Davies, J., \& Brember, I. (2001). The closing gender gap in attitudes between boys and girls: A 5-year longitudinal study. Education Psychology, 21, 103-114. https://doi.org/10.1080/01443410124899

Diseth, A. (2011). Self-efficacy, goal orientations and learning strategies as mediators between preceding and subsequent academic achievement. Learning and Individual Differences, 21(2), 191-195. https://doi.org/10.1016/j.lindif.2011.01.003

Diseth, A., Pallesen, S., Hovland, A., \& Larsen, S. (2006). Course experience, approaches to learning and academic achievement. Education and Training, 48, 156-169. https://doi.org/10.1108/00400910610651782

Education Commission, HKSAR. (2000). Learning for Life, Learning through Life - Reform Proposals for the Education System in Hong Kong. Final Report of the Education Commission, HKSAR, PRC.

Entwistle, N. (2009). Teaching for understanding at university: Deep approaches and distinctive ways of thinking. Basingstoke, UK: Palgrave Macmillan.

Entwistle, N., \& Peterson, E. (2004). Conceptions of learning and knowledge in higher education: Relationships with study behavior and influences of learning environments. International Journal of Educational Research, 41, 407-428. https://doi.org/10.1016/j.ijer.2005.08.009

Fenollar, P., Roman, S., \& Cuestas, P. J. (2007). University students' academic performance: An integrative conceptual framework and empirical analysis. British Journal of Educational Psychology, 77(4), 873-891. https://doi.org/10.1348/000709907X189118

Findley, M. J., \& Cooper, H. M. (1983). Locus of control and academic achievement: A literature review, Journal of Personality and Social Psychology, 44(2), 419-427. https://doi.org/10.1037/0022-3514.44.2.419 


\section{$\triangle$ Macrothink}

Global Journal of Educational Studies ISSN 2377-3936 2017, Vol. 3, No. 1

Furnham, A., Chamorro-Premuzic, T., \& McDougall, F. (2003). Personality, cognitive ability and beliefs about intelligence as predictors of academic performance. Learning and Individual Differences, 14, 49-66. https://doi.org/10.1016/j.lindif.2003.08.002

Hay, D. B. (2007). Using concept maps to measure deep, surface and non-learning outcomes. Studies in Higher Education, 32(1), 39-57. https://doi.org/10.1080/03075070601099432

Ho, I. T., \& Hau, K. T. (2008). Academic achievement in the Chinese context: The role of goals, strategies, and effort. International Journal of Psychology, 43(5), 892-897. https://doi.org/10.1080/00207590701836323

Jonassen, D. H., \& Grabowski, B. L. (1993). Handbook of Individual Differences Learning and Instruction. Hillsdale, NJ: Lawrence Erlbaum Associates.

Kember, D., Hong, C., Ho, A., \& Ho, A. (2011). More can mean less motivation: Applying a motivational orientation framework to the expanded entry into higher education in Hong Kong. Studies in Higher Education, 36(2), 209-225. https://doi.org/10.1080/03075070903514062

Lee, W. C., \& Young, C. M. (2003). Pioneering the community college movement in Hong Kong. International Journal of Lifelong Education, 22(2), 147-158. https://doi.org/10.1080/0260137032000055312

Lizzio, A., Wilson, K., \& Simons, R. (2002). University students' perceptions of the learning environment and academic outcomes: Implications for theory and practice. Studies in Higher Education, 27(1), 27-52. https://doi.org/10.1080/03075070120099359

McAuley, E., Duncan, T. E., \& Russell, D. W. (1992). Measuring causal attributions: The Revised Causal Dimension Scale (CDSII). Personality and Social Psychology, 18(5), 566-573. https://doi.org/10.1177/0146167292185006

McKenzie, K., \& Schweitzer, R. (2001). Who succeeds at university? Factors predicting academic performance in first year Australian university students. Higher Education Research and Development, 20(1), 21-33. https://doi.org/10.1080/07924360120043621

Meinz, E. J., \& Salthouse, T. A. (1998). Is age kinder to females than to males? Psychonomic Bulletin and Review, 5, 56-70. https://doi.org/10.3758/BF03209457

Prat-Sala, M., \& Redford, P. (2010). The interplay between motivation, self-efficacy, and approaches to studying. British Journal of Educational Psychology, 80(2), 283-305. https://doi.org/10.1348/000709909X480563

Richardson, J. (2006). Investigating the relationship between variations in students' perceptions of their academic environment and variations in study behaviour in distance education. British Journal of Educational Psychology, 76(3), 867-893. https://doi.org/10.1348/000709905X69690

Richardson, J. T. E., \& King, E. (1991). Gender differences in the experience of higher education: Qualitative and quantitative approaches. Educational Psychology, 11(3), 363-382. 
https://doi.org/10.1080/0144341910110311

Scouller, K., \& Prosser, M. (1994). Students' experiences in studying for multiple-choice question examinations. Studies in Higher Education, 19(3), 267-279. https://doi.org/10.1080/03075079412331381870

Sins, P. H. M., Van Joolingen, W. R., Savelsbergh, E. R., \& Van Hout-Wolters, B. (2008). Motivation and performance within a collaborative computer-based modeling task: Relations between students' achievement goal orientation, self-efficacy, cognitive processing, and achievement. Contemporary Educational Psychology, 3(1), 58-77. https://doi.org/10.1016/j.cedpsych.2006.12.004

Smith, J., \& Naylor, R. (2001). Determinants of degree performance in UK universities: A statistical analysis of the 1993 student cohort. Oxford Bulletin of Economics and Statistics, 63, 29-60. https://doi.org/10.1111/1468-0084.00208

Sternberg, R. J. (1997). Thinking styles. New York: Cambridge University Press. https://doi.org/10.1017/CBO9780511584152

Sue, S., \& Okazaki, S. (1990). Asian American educational achievement: A phenomenon in search of an explanation. American Psychologist, 45(8), 913-920. https://doi.org/10.1037/0003-066X.45.8.913

Thomas, K. (1988). Gender and the arts/science divide in higher education. Studies in Higher Education, 13(2), 123-137. https://doi.org/10.1080/03075078812331377816

Trigwell, K., Ashwin, P., \& Millan, E. S. (2013). Evoked prior learning experience and approach to learning as predictors of academic achievement. British Journal of Educational Psychology, 83(3), 363-378. https://doi.org/10.1111/j.2044-8279.2012.02066.x

Watkins, D. (1984). Student learning processes: An exploratory study in the Philippines. Human Learning, 3, 33-42.

Watkins, D., \& Biggs, J. B. (2001). The paradox of the Chinese learner and beyond. In D. Watkins, \& J. B. Biggs (Eds.), Teaching the Chinese learner (pp. 3-26). Hong Kong: University of Hong Kong, Comparative Education Research Centre.

\section{Copyright Disclaimer}

Copyright for this article is retained by the author(s), with first publication rights granted to the journal.

This is an open-access article distributed under the terms and conditions of the Creative Commons Attribution license (http://creativecommons.org/licenses/by/3.0/). 